naty zostały opatrzone krótkimi historycznymi informacjami na temat pochodzenia zabawki, jej wyrobu itp. Dla dzieci przygotowano niespodzianki - można „pojeździć konno" na drewnianym koniku, strzelać z łuku, zbudować fortece z piasku, a także poczuć się jak aktor teatru animacji podczas przedstawienia, bawiąc się lalkami. Wiele z przedmiotów można stworzyć samodzielnie, wzorując się na historycznych modelach.

W drugiej sali można było zobaczyć różnorodne wyposażenie towarzyszące dziecku od narodzin do częstej przecież śmierci w dzieciństwie. Zwiedzający mógł podziwiać kołyski zawieszone u belki stropowej, oraz kołyski stojące, sposób zawinięcia niemowlęcia w tzw. powijaki, naczynia do karmienia dzieci itp. Eksponatom towarzyszyła bogata ilustracja zdjęciowa, wzbogacona cytatami z różnych źródeł historycznych. Ponadto można było obejrzeć sprzęty codziennego użytku, np.: piec z garnkami do warzenia strawy, krosno do wyrobu odzieży, a także stroje dziecięce. Dla najmłodszych zwiedzających w tej części przygotowano m.in. odczytywanie najstarszych bajek (pochodzących z końca XVII w.) Ostatni aspekt wystawy został poświęcony śmierci dziecka - zawierał różne źródłowe opisy bólu rodziców po śmierci dziecka, a także kolekcję sarkofagów, płyt i portretów trumiennych, będących świadectwem swoistego oswajania śmierci, która nie była niczym nadzwyczajnym w ówczesnych realiach.

Wystawę można było oglądać w Muzeum Archeologicznym w Poznaniu w dniach 1 lipca - 30 września 2009 r.

Katarzyna Kabacińska

Krzysztof Ratajczak

\title{
Sympozjum Historii Edukacji na XVIII Powszechnym Zjeździe Historyków Polskich w Olsztynie, 16-19 września 2009 r.
}

W dniach 16-19 września 2009 r. odbył się w Olsztynie XVIII Powszechny Zjazd Historyków Polskich - hasłem tegorocznego spotkania był „Powrót do źródeł”. Pierwszego dnia obrad zorganizowano aż 18 specjalistycznych sympozjów, które obejmowały szeroki zakres problematyki od czasów starożytnych aż do okresu PRL-u, uwzględniając m.in.: historię wojskowości, dzieje medycyny i farmacji, demografię historyczną, biografistykę, historię gospodarczą, geografię historyczną, dzieje parlamentaryzmu, historię prasy, historię nauki i metodologię historii. Na zjeździe nie zabrakło także historyków wychowania, którzy dyskutowali o największych wyzwaniach edukacyjnych od średniowiecza do współczesności w ramach 11 sympozjum poświęconego historii edukacji. Organizatorami tego sympozjum byli prof. Władysława Szulakiewicz z Uniwersytetu Mikołaja Kopernika w Toruniu oraz prof. Karol Poznański z Akademii Pedagogiki Specjalnej im. Marii Grzegorzewskiej w Warszawie. 
W ramach obrad sympozjum historii edukacji wysłuchano 12 referatów, które dotyczyły dziejów szkolnictwa, historii teorii pedagogicznej oraz historii środowisk edukacyjnych. Ich autorzy reprezentowali uczelnie wyższe Gdańska (Uniwersytet Gdański), Krakowa (Uniwersytet Pedagogiczny im. Komisji Edukacji Narodowej), Łodzi (Uniwersytet Łódzki), Poznania (Uniwersytet im. Adama Mickiewicza), Słupska (Akademia Pedagogiczna), Torunia (Uniwersytet Mikołaja Kopernika), Warszawy (Akademia Pedagogiki Specjalnej im. Marii Grzegorzewskiej) oraz Wrocławia (Uniwersytet Wrocławski, Dolnośląska Szkoła Wyższa).

Spotkanie rozpoczął prof. Karol Poznański, który nawiązując do tematu przewodniego sympozjum „Największe wyzwania edukacyjne od średniowiecza do współczesności" przedstawił refleksje dotyczące polskich tradycji edukacyjnych od momentu założenia uniwersytetu w Krakowie do czasów współczesnych. Wskazując na najważniejsze dokonania w tym zakresie zaznaczył zarówno znaczenie rozwoju polskiego szkolnictwa - od szkół innowierczych, przez najsłynniejsze placówki doby Oświecenia i okresu zaborów, aż do tajnego nauczania w okresie II wojny światowej i współczesnego intensywnego rozwoju szkolnictwa wyższego - jak i myśli pedagogicznej. Podkreślił, że Polacy wielokrotnie stawali przed trudnymi wyzwaniami tworzenia niejako od początku, w oparciu o zupełnie nowe podstawy prawne i ideologiczne, rodzimego systemu oświaty.

Tradycję uczestnictwa historyków wychowania w Powszechnych Zjazdach Historyków Polskich przedstawiła prof. Władysława Szulakiewicz. Zwróciła uwagę na rolę i znaczenie samych zjazdów oraz podkreśliła, że historycy wychowania, zanim w roku 1948 na zjeździe we Wrocławiu utworzono po raz pierwszy specjalistyczną podsekcję historii wychowania, uczestniczyli głównie w sekcjach obejmujących historię kultury i literatury, zabierali ponadto głos w sprawach archiwistyki oraz dydaktyki historii. Zasiadali także w gremiach kierowniczych Polskiego Towarzystwa Historycznego. Szczególnie istotne dla historyków wychowania były zjazdy z roku 1900 i 1925 . Wówczas to najpierw Antoni Karbowiak, a później Stanisław Łempicki przedstawili istotne postulaty dotyczące dalszego rozwoju tej dyscypliny naukowej. Znaczący był także pierwszy powojenny zjazd, w roku 1948 we Wrocławiu, na którym ważne referaty wygłosili Bogdan Suchodolski, Łukasz Kurdybacha i Stefan Truchim. Oceniając kwestię reprezentacji środowiska historyków wychowania w tego typu spotkaniach naukowych prof. W. Szulakiewicz zaznaczyła, że w okresie międzywojennym był on znaczący i to nie tylko na zjazdach historyków, ale także polonistów oraz na kongresach pedagogicznych. Po II wojnie światowej znaczna grupa historyków wychowania wywodziła się ze środowiska pedagogów i dlatego częściej uczestniczyli oni w zjazdach pedagogicznych niż historycznych. Wśród problematyki referatów historyczno-oświatowych wygłoszonych na Powszechnych Zjazdach Historyków Polskich wyróżnić można trzy podstawowe bloki tematyczne, które dotyczyły stanu i organizacji badań oraz kwestii metodologicznych, zagadnień dydaktyki historii, a także historii nauki, kultury i życia umysłowego, ze szczególnym uwzględnieniem problematyki uniwersytetów.

Jak zatem na tym tle prezentuje się uczestnictwo historyków wychowania w XVIII Powszechnym Zjeździe Historyków Polskich? W ramach pierwszej części obrad sympozjum wygłoszono 6 referatów dotyczących dziejów szkolnictwa. Prof. Dorota Żołądź- 
-Strzelczyk, z Uniwersytetu im. Adama Mickiewicza w Poznaniu, wygłosiła referat dotyczący „Szkolnictwa różnowierczego w Wielkopolsce”, w którym podkreśliła zarówno wpływ czynników sprzyjających jego intensywnemu rozwojowi, jak i hamujących dalszą ekspansję. Zaznaczyła znaczenie instytucji scholarchatu oraz rozbudowanego systemu stypendiów na edukacyjne wyjazdy zagraniczne. Prof. Jerzy Kochanowicz, z Dolnośląskiej Szkoły Wyższej we Wrocławiu, zaprezentował zagadnienie „Bezpłatności jezuickich uniwersytetów jako przyczyny sporów z Akademią Krakowską", skupiając się nie tylko na formach, lecz także przyczynach bezpłatności szkół jezuickich oraz argumentacji uczelni krakowskiej i samych jezuitów w sporach o utworzenie uczelni w Poznaniu. Prof. Julian Dybiec, z Uniwersytetu Jagiellońskiego, omawiając „Ideę uniwersytetu w polskiej humanistyce XX wieku” zaznaczył, że dyskusje nad rodzimym ,idealnym" modelem uczelni wyższej pojawiały się zawsze w przełomowych dla Polski momentach historycznych. Przybliżył m.in. koncepcje organizacji uniwersytetu autorstwa Stanisława Staszica, Kazimierza Brodzińskiego, Józefa Dietla, Kazimierza Twardowskiego i Zygmunta Łempickiego. Wyraźnie zaznaczył, że uczelnie wyższe zawsze, także współcześnie, powinny służyć prawdzie a nie uzasadnieniu polityki historycznej. Prof. Roman Tomaszewski, z Akademii Pedagogicznej w Słupsku, w swoim referacie zatytułowanym „Koncepcja uczelni wojskowej w Polsce XX wieku (między edukacyjną autarkią a otwarciem)" przedstawił wyzwania w zakresie edukacji kadr wojskowych oraz niezrealizowane, jak dotąd, dążenia do urzeczywistnienia wizji wojskowego uniwersytetu i politechniki. Podkreślił, że Wojskowa Akademia Techniczna nie w pełni zaspokoiła oczekiwania środowisk wojskowych. Prof. Grzegorz Michalski, z Uniwersytetu Łódzkiego, omawiając „Oświatową i edukacyjną działalność inspektorów szkół średnich” wskazał na miejsce i rolę inspektorów w systemie oświatowym II Rzeczypospolitej oraz scharakteryzował ich pracę w Związku Inspektorów. Zaznaczył, że była to nieliczna i jedyna korporacja przyjmująca w tamtym okresie członków nadzoru pedagogicznego. Skupiała ona ludzi o różnych światopoglądach, którym ostatecznie udało się wypracować własną wizję szkolnictwa i zasad pracy inspektorów szkolnych. Prof. Stefania Walasek, z Uniwersytetu Wrocławskiego, przedstawiając zagadnienie „Unifikacji szkolnictwa Kresów Północnych po 1922 roku” zwróciła uwagę zarówno na trudności w dostosowywaniu się Kresów do systemu szkolnego II Rzeczypospolitej, jak i na niezaprzeczalny dorobek oświatowy tych terenów. Zaznaczyła przede wszystkim rolę Uniwersytetu w Wilnie jako silnego ośrodka polskiej kultury i nauki oraz międzykulturowy model edukacji realizowany przez uniwersytet ludowy w Krzemieńcu.

Po zakończeniu tej części obrad rozpoczęła się ożywiona dyskusja dotycząca przede wszystkim kwestii metodologicznych, bazy źródłowej oraz nowych kierunków badań historyczno-oświatowych. Prof. J. Dybiec, nawiązując do referatu prof. J. Kochanowicza, zwrócił uwagę na to, że istota konfliktu jezuitów z Akademią Krakowską nie tkwi w argumentacji, którą obydwie strony przedstawiały na sejmikach czy w apelacjach wysyłanych do Rzymu. Przypomniał, że już Jan Brożek w swoim dziele Gratis (spalonym zresztą publicznie przez kata) wyraźnie podkreślił, że szkoły jezuickie w istocie nie są bezpłatne, gdyż podstawą ich utworzenia jest zawsze ogromna fundacja zapewniająca tym placówkom luksusowe warunki funkcjonowania. Z pewnością Akademia Krakow- 
ska obawiała się utraty studentów, a wraz z nimi części wpływów z taks immatrykulacyjnych, które stanowiły jedno z istotnych źródeł dochodu uczelni. Warto zatem sprawdzić, ile dokładnie kosztowały studia w Krakowie, być może te spory ograniczały się jedynie do owych taks immatrykulacyjnych. Ponadto prof. J. Dybiec zauważył, że Akademii zależało przede wszystkim na możliwościach wywierania wpływu na społeczeństwo przez właściwie zorganizowaną edukację, która zapewniała kształtowanie w obywatelach pożądanych postaw. Uniwersytet Krakowski obawiał się zatem utraty tych wpływów, które także dzisiaj mają istotne znaczenie, a zatem prestiżu i ważnego miejsca w systemie edukacyjnym Rzeczypospolitej. Podważył też tezę wysuniętą przez Stanisława Bednarskiego i przyjętą później przez wielu badaczy, o negatywnym wpływie konfliktu jezuitów z Akademią na polską myśl pedagogiczną tamtego okresu. Prof. J. Dybiec ocenił, że nawet gdyby nie było tych sporów, to i tak doszłoby do stagnacji w tym zakresie na skutek wielu problemów gospodarczych i społecznych, a także ze względu na mentalność szlachty polskiej i jej upodobanie do zagranicznej edukacji. Wszystkie te okoliczności wpłynęły na opustoszenie szkół, co ostatecznie spowodowało ogólną stagnację w dziedzinie edukacji i myśli pedagogicznej. Natomiast prof. K. Poznański podkreślił, że prof. Jan Dobrzański często zaznaczał, że jezuici byli przede wszystkim kaznodziejami i spowiednikami na dworach królewskich i właśnie dzięki zdobytym w ten sposób wpływom uzyskali znaczne fundusze na uruchomienie własnych szkół. Wspomniał także o tym, że jezuici w znacznym stopniu upowszechniali ogólną kulturę wśród swoich uczniów, jednak zawsze istniał w ich szkołach dystans pomiędzy nauczycielami a uczniami, którzy tworzyli dwa zupełnie odrębne światy i nawet datki składane przez rodziców na poczet nauki potomstwa, zupełnie tego dystansu nie skracały.

Prof. J. Dybiec, odnosząc się do referatu prof. R. Tomaszewskiego spytał o przyczyny braku popularności niemieckiego (pruskiego) modelu kształcenia wojskowego w Polsce i zakres tłumaczenia na język polski prac z teorii wojskowości. Zwrócił też uwagę na to, że na popularność innych modeli wpływ miała m.in. znaczna liczba absolwentów rosyjskich szkół wojskowych, urok szkół wiedeńskich, takich jak Teresianum czy niewygasająca w Polsce od XVIII w. atrakcyjność kultury francuskiej. Prof. R. Tomaszewski odpowiedział, że w Polsce w latach 1916-1921 szczególnie obecny był model niemieckiego szkolnictwa wojskowego, który następnie wraz z pojawieniem się francuskiej misji wojskowej został zastąpiony przez model francuski. Eliminacji wzorów niemieckich sprzyjała także niechęć Józefa Piłsudskiego wobec nich. Pewne próby wymiany myśli wojskowej z Niemcami podjęto w latach 1934-1937, wcześniej po roku 1928 ożywione kontakty w tych kwestiach utrzymywano z Włochami i Francją. Ogólnie do roku 1935 obywatele Europy niechętnie podejmowali zagadnienia wojskowe, a w późniejszym okresie rozwój ideologii totalitarnych nie sprzyjał wymianie myśli wojskowej. Natomiast tłumaczenia literatury zagranicznej do lat 30 . XX w. były zbędne - polscy wojskowi znali bowiem język niemiecki i rosyjski, później jednak podejmowano takie działania. Prof. K. Poznański zauważył, że nie posiadamy zbyt wielkiego dorobku w dziedzinie szkolnictwa wojskowego, co w znacznej mierze jest skutkiem niekorzystnego dla Polski układu sił politycznych. Wiek XVII nie sprzyjał w naszym kraju rozwojowi własnej myśli wojskowej, natomiast okres międzywojennego odprężenia trwał zbyt krótko, 
by można było wówczas stworzyć zwartą doktrynę wojskową, natomiast po 1945 r. ideologizacja objęła także tę sferę. Nie ma także zbyt wielu prac na ten temat - jest to zatem współcześnie interesujący obszar badawczy.

Dr Andrzej Szmyt, z Uniwersytetu Warmińsko-Mazurskiego, odnosząc się do referatu prof. S. Walasek podkreślił, że Liceum Krzemienieckie w okresie II Rzeczypospolitej było właściwie szerokim zespołem szkół obejmującym nawet szkoły wieczorowe i wakacyjne. Zaznaczył także międzykulturowy charakter tamtejszej edukacji - wśród uczniów szkoły w Krzemieńcu było wielu Ukraińców i Żydów, a w 1 połowie XIX w. przyjeżdżali do niej uczniowie z terenu całej Polski. Przypomniał także, że szkoła organizowana przez Tadeusza Czackiego stanowiła w pewnym sensie kontynuację szkolnictwa jezuickiego, a obecnie w Krzemieńcu znajduje się szkoła wyższa, której rektor, podobnie jak Czacki kiedyś, myśli o uruchomieniu w mieście uniwersytetu. Natomiast dr Teresa Jaroszuk, z Uniwersytetu Warmińsko-Mazurskiego, zauważyła, że to przede wszystkim nauczyciele, a nie programy, odegrali najważniejszą rolę w integracji Kresów z całością ziem Rzeczypospolitej. Wskazała na literaturę pamiętnikarską, która porusza te niezwykle ciekawe zagadnienia m.in. Świat w szkole: pamiętnik nauczycielki Eugenii Kobylińskiej.

Prof. J. Dybiec, nawiązując do referatu prof. D. Żołądź-Strzelczyk zaznaczył, że to właśnie szkolnictwu innowierczemu zawdzięczamy ,gorliwość” w krzewieniu oświaty, przewyższającą nawet „gorliwość” jezuitów. Szczególnie podkreślił ważność misji edukacyjnej różnowierstwa na terenie Wielopolski, którą charakteryzowała nieco odmienna sytuacja społeczno-gospodarcza niż inne tereny Polski - pogłębiona później przez konfrontację z zaborcą pruskim, oraz formy działalności oświatowej tamtejszych innowierców. Prof. K. Poznański zwrócił też uwagę na możliwość pejoratywnego odbioru określenia „różnowierczy”, zaproponował, by jednak różnicować zwolenników Lutra, husytów czy arian, oraz na wielką siłę, która tkwiła także w szkolnictwie innowierczym na pozostałych terenach Polski, np. w Małopolsce. Prof. D. Żołądź-Strzelczyk podkreśliła, że na synodach różnowierczych często podejmowano szeroko rozumiane kwestie edukacyjne. Innowiercy propagowali m.in. wychowanie w domu seniora, dotyczyło to głównie przyszłych duchownych i ministrów, którzy mieli obowiązek przyjmowania chłopców na wychowanie. Propagowali także akcję wysyłania młodzieży na studia zagraniczne na koszt zboru; ci, którzy skorzystali z takiej formy pomocy podpisywali zobowiązanie, że po powrocie do kraju odpracują równowartość odebranego stypendium. Prof. D. ŻołądźStrzelczyk zauważyła też, że trudno uniknąć stosowania globalnego terminu ,różnowierczy” - nie można go bowiem zawsze zastąpić np. określeniem ,protestancki”, który ma zdecydowanie węższe znaczenie.

Prof. W. Szulakiewicz, nawiązując do referatu prof. J. Dybca, zaznaczyła, że w przypadku autorów koncepcji funkcjonowania polskich uczelni wyższych istotne znaczenie ma to, jak mocno byli oni zaangażowani w sprawy uniwersyteckie. Najwybitniejsi z nich byli znawcami zarówno teoretycznych, jak i praktycznych aspektów działalności uniwersytetów, i dlatego też ich koncepcje nie były wytworami idealnymi.

Po zakończeniu dyskusji uczestnicy sympozjum wysłuchali pięciu referatów dotyczących historii teorii pedagogicznej oraz historii środowisk edukacyjnych. Dr Jan Ryś, 
z Uniwersytetu Pedagogicznego im. Komisji Edukacji Narodowej w Krakowie, przedstawił, przygotowany wspólnie z prof. Janem Krukowskim, referat na temat „Wkład krakowskiego środowiska w rozwój teorii i praktyki nauczania (XV-XV w.)”. Podkreślając, że brak do tej pory wyczerpującego opracowania tych zagadnień przybliżył m.in. dokonania takich krakowskich uczonych z tego okresu, jak Paweł z Worczyna, Benedykt Hesse, Jan z Ludziska, Stanisław Szydłowiecki, Andrzej Frycz Modrzewski czy Łukasz Górnicki. Zaznaczył także obecność w Krakowie zagranicznych uczonych, którzy wygłaszali swoje wykłady na uniwersytecie. Dr Iwonna Michalska, z Uniwersytetu Łódzkiego, omówiła „Działalność Naukowego Towarzystwa Pedagogicznego (1928-1958) na rzecz rozwoju nauk o wychowaniu". Podkreśliła elitarny charakter tej organizacji oraz podstawowe formy jej działalności i osiągnięte efekty. Zwróciła uwagę na intensywny rozwój prac Towarzystwa w okresie międzywojennym i jego zdecydowane zahamowanie w nowej rzeczywistości ukształtowanej po zakończeniu II wojny światowej. Zaakcentowała wpływ tej organizacji na konsolidację, integrację i uaktywnienie środowisk akademickich w Polsce. Dr Agnieszka Wałęga, z Uniwersytetu Mikołaja Kopernika w Toruniu, przedstawiła „Koncepcje podręcznika historii wychowania - w świetle propozycji autorów i opinii recenzentów". Uwzględniając zarówno najstarsze, pochodzące z 2 połowy XIX w., jak i najnowsze wydawnictwa tego typu zaprezentowała zagadnienie ewolucji poglądów środowisk historyków wychowania i pedagogów dotyczących modelu podręcznika do nauczania tego przedmiotu. Mgr Joanna Falkowska, z Uniwersytetu Mikołaja Kopernika w Toruniu, przedstawiła referat pt. „Wychowanie narodowe jako wyzwanie dla polskiej edukacji. Poglądy Stanisława Pigonia (1885-1968)”. Szczególną uwagę zwróciła na koncepcje Pigonia dotyczące kształtowania narodu polskiego przez właściwy program nauczania i wychowania oraz jego rozróżnienie patriotyzmu i egoizmu narodowego. Prof. Krzysztof Jakubiak z Uniwersytetu Gdańskiego wygłosił przygotowany wspólnie z prof. Wiesławem Jamrożkiem, z Uniwersytetu im. Adama Mickiewicza w Poznaniu, referat pt. „Rodzina jako środowisko wychowawcze w XIX i XX wieku”. Prof. Jakubiak przedstawił trzy podstawowe modele ówczesnej rodziny: szlachecki (ziemiański), mieszczański i chłopski. Zaznaczył, że model rodziny polskiej przełomu XIX i XX w. był dość uniwersalny i przez to możliwy do akceptacji przez większość grup społecznych.

Po zakończeniu tej części obrad rozpoczęto dyskusję. Wiele uwagi poświęcono w niej kwestii źródeł do badań nad dziejami rodziny oraz uwzględnieniu tej problematyki w nauczaniu historii. Prof. J. Dybiec, nawiązując do ostatniego z wygłoszonych referatów zauważył, że pewne cechy wytwarzane przez środowisko domowe miały raczej charakter naturalistyczny, niż związany z przynależnością do określonych grup społecznych. Wspomniał także o znanych sobie przykładach przetrwania, aż do lat 60 . XX w., silnego patriarchatu w rodzinach i bezwzględnego posłuszeństwa dzieci wobec starszych. Prof. Poznański zwrócił także uwagę na interesujące, a niewykorzystane w dotychczasowych badaniach, bazujących głównie na pamiętnikach, wspomnieniach i prasie, źródła do badań nad dziejami rodziny. Wymienił wśród nich m.in. księgi odnotowujące kary, nagrody i uwagi nauczycieli o młodzieży, która pobierała naukę w szkołach, zdeponowane m.in. w lubelskich archiwach i zawierające niezwykle interesujący materiał, oraz różnego ro- 
dzaju akta sądowe, spadkowe czy testamenty. Prof. dr hab. Grażyna Pańko, z Uniwersytetu Wrocławskiego, podkreśliła, że referat prof. K. Jakubiaka i W. Jamrożka charakteryzował wartości, które funkcjonują w większości rodzin chłopskich do dziś. Zauważyła także, że obecnie rośnie potrzeba rejestrowania informacji o dziejach wychowania w rodzinie, zwłaszcza od osób starszych, np. słuchaczy Uniwersytetów Trzeciego Wieku. Dr hab. Bogumiła Burda, z Uniwersytetu Zielonogórskiego, autorka podręcznika do nauczania historii, zwróciła uwagę na blok tematyczny dotyczący rodziny obecny w nauczaniu historii w szkole podstawowej i konieczność zaznajomienia uczniów, już na tym etapie edukacji, ze zjawiskami zmienności modelu rodziny na przestrzeni wieków. Podkreśliła też znaczenie materiałów ikonograficznych jako środka dydaktycznego w nauczaniu o dziejach rodziny.

W trakcie dyskusji uczestnicy sympozjum proponowali także kontynuowanie badań w zakresie podejmowanych przez referentów zagadnień, wskazując interesujące problemy badawcze. Prof. K. Poznański zgłosił pytanie do referatu dr I. Michalskiej: Jak to się stało, że w okresie, gdy polska myśl pedagogiczna po przełomie październikowym wyzwalała się z wcześniej obowiąujących schematów, gdy aktywnie działały takie postaci, jak Bogdan Suchodolski, Bogdan Nawroczyński, Zygmunt Mysłakowski czy Kazimierz Sośnicki, doszło do likwidacji Naukowego Towarzystwa Pedagogicznego?. Warto, w toku dalszych badań, poszukać przyczyn tego zjawiska, tym bardziej, że Towarzystwo przetrwało jednak najgorsze czasy stalinowskie - czy do jego likwidacji doszło dlatego, że było ono zbyt ekskluzywne, czy też wplyw miaty na to inne ,,zakulisowe” czynniki. Prof. J. Dybiec, odnosząc się do referatu mgr J. Falkowskiej zaznaczył, że szczególnie interesujące byłoby prześledzenie zjawiska ewoluowania poglądów S. Pigonia od czasów wczesnych związków z romantycznym ruchem Eleusis, po jego późniejsze bardziej racjonalistyczne stanowisko. Podniósł także kwestię trudności w wyraźnym oddzieleniu koncepcji wychowania narodowego od wychowania humanistycznego. Wskazał także na interesujący problem badawczy dotyczący roli socjalistycznego modelu rodziny, szczególnie w porównaniu z jej wizją katolicką.

Uczestnicy dyskusji wyrazili też swoje opinie dotyczące najnowszych podręczników do nauczania historii wychowania. Prof. R. Tomaszewski podkreślił szereg czynników, które wpływają na trudności stojące obecnie przed autorami wydawnictw podręcznikowych z zakresu historii wychowania, odniósł to także do wcześniejszych doświadczeń w tym zakresie. Prof. J. Dybiec dodał, że autorzy podręczników w przeszłości ulegali wpływom ideologicznym, natomiast współcześnie zagraża im obsesja antykomunistyczna oraz nadmierne przestrzeganie zasady poprawności politycznej. Natomiast prof. K. Poznański przywołał okoliczności powstania akademickiego podręcznika pod redakcją Łukasza Kurdybachy oraz wydawnictwa opracowanego przez Stefana Wołoszyna, które w momencie ich opublikowania stanowiły dla siebie swoistą konkurencję.

Po zakończeniu obrad i dyskusji organizatorzy sympozjum podziękowali wszystkim uczestnikom i zapowiedzieli druk materiałów pozjazdowych.

Na XVIII Powszechnym Zjeździe Historyków Polskich w Olsztynie historycy wychowania, kontynuując zapoczątkowaną przed 60 laty, w roku 1948 r., tradycję, obradowali w ramach specjalistycznego sympozjum. Należy podkreślić raz jeszcze, że referen- 
ci reprezentowali liczne krajowe ośrodki naukowe, a poruszana przez nich problematyka obejmowała szeroki zakres i to zarówno tematyczny, jak i chronologiczny. Ożywione dyskusje uczestników obrad świadczą nie tylko o szerokich możliwościach dalszych badań historyczno-oświatowych, lecz i o konieczności organizowania kolejnych tego typu spotkań.

Agnieszka Wałęga

\section{Ogólnopolska Konferencja Naukowa „Opieka - Wychowanie - Resocjalizacja. Tradycja i problemy współczesne"}

W dniach 5-6 października 2009 r. w Ustce odbyła się Ogólnopolska Konferencja Naukowa, której założeniem było zainicjowanie cyklu spotkań obejmujących nie tylko rozważania teoretyczne i prezentację wyników badań empirycznych, ale także nawiązanie ścisłej współpracy między ośrodkami naukowymi w kraju w celu wypracowania rozwiązań praktycznych służących rozwiązywaniu ważnych społecznie problemów w środowisku lokalnym i ogólnopolskim.

Organizatorem konferencji był Instytut Pedagogiki Akademii Pomorskiej w Słupsku, a honorowy patronat objęły władze regionu słupskiego - Prezydent Miasta Słupska oraz Burmistrz Miasta Ustki.

Uczestnikami konferencji byli przedstawiciele świata naukowego z ośrodków akademickich całej Polski: historycy, pedagodzy, psycholodzy i prawnicy, a także specjaliści związani z praktycznym działaniem na polu opieki, wychowania i resocjalizacji: przedstawiciele prawa i medycyny, nauczyciele, policjanci oraz pracownicy socjalni. W obradach wzięli także aktywny udział studenci Akademii Pomorskiej, wśród nich osoba o znacznym stopniu niepełnosprawności, która własnym przykładem wskazała możliwości pokonywania barier oraz określone rozwiązania praktyczne w stymulowaniu rozwoju osób niepełnosprawnych.

Konferencja obejmowała dwudniową sesję plenarną oraz trzy sekcje tematyczne dotyczące:

I. Obszarów opieki i wychowania na przełomie wieków w ujęciu historycznym;

II. Współczesnych kierunków rozwoju teorii i praktyki opiekuńczo-wychowawczej;

III. Tradycyjnych i współczesnych kierunków rozwoju teorii i praktyki resocjalizacji.

Szczególnie cenionym przez prelegentów i zaproszonych gości aspektem obrad była ich interdyscyplinarność. W przeciwieństwie do znacznej części spotkań naukowych, 